\title{
TO CARMELO CUNCHILLOS, WITHOUT WHOM NOT
}

\author{
Pedro SANTANa MartíneZ
}

In this issue of Journal of English Studies his colleagues pay homage to Carmelo Cunchillos, maestro $y$ amigo, to use the two Spanish words that best express what Carmelo has been and still is for so many. This homage in his retirement has adopted the form that is to be expected from the academic tribe: the offering and publication of the best results of their research, the fruits of their quest for knowledge.

Carmelo Cunchillos has taught English language and literature at the universities of Zaragoza and La Rioja for more than thirty years. He founded the Department of Modern Languages at the University of La Rioja and has contributed to the development of English Studies as a discipline in Spain not only as a professor and researcher but also - and specially in the 1990s - as an active member of the boards of the Asociación Española de Estudios Anglo-norteamericanos (AEDEAN) and of the European Society for the Study of English (ESSE).

If human creations are the result of the efforts of many, sometimes it is not difficult to tell a name among the others, to mention a person without whom things in our small part of the world would not have been what they are. The discipline of English Studies at the Universidad de La Rioja provides us with a good illustration of those particular occasions on which the main impulse of a collective enterprise is owed to one individual. For the essential momentum that produced the present reality of the discipline at this university and the fruits achieved by its practitioners owe much to Professor Carmelo Cunchillos. He was the first Head of the Department of Modern Languages, Catedrático de Filología Inglesa, an academic figure recognised by many colleagues of Europe and America. 
However, one suspects that, once all the external details and data have been reviewed under the doubtful light of academic scrutiny, what finally counts is not the scientific and professional career such as it is reflected in biographies and curricula vitae. For there are aspects in a person's life that remain intangible to those who do not know him and that are almost impossible to express in words to those who know him well. Professor Cunchillos has always had much to give and to teach concerning this difficult chapter of the things that really count for he has been not only a teacher but also a friend of all the academics that initiated their careers under his example and tutorship.

For years Carmelo Cunchillos has taught English language and literature to both undergraduate and graduate students and, in doing so, he has done something more, something that reveals the true essence of this profession. Because it was not only the language and the literature that gives words their true value what Carmelo was able to teach, or, rather, to discover to his students: what he did was to show us the way in which literature permeates our lives, to prove that literature, its words and ideas are part of the stuff we are made of.

And there were more things in Carmelos's lessons. There is still the deep and true interest for the human side of science, which is precisely what a master must know how to transmit to their pupils.

Some were fortunate enough to enjoy Carmelo's teachings and writings, his way of presenting and questioning the works of the great authors, his way of making them our contemporaries, for literature is simply another word for naming the present time, this time which you, Carmelo, have enriched with your inspiring example. 